\title{
Correlation between F2-Isoprostane with stromal cell-derived factor-1 (SDF-1) and endothelial progenitor cell in nonhypertensive and hypertensive patients
}

\author{
Johnson Wijaya, ${ }^{1}$ Syakib Bakri, ${ }^{1}$ Marsetio Donosepoetro ${ }^{1}$ \\ ${ }^{1}$ Faculty of Medicine, Hasanuddin University, Makassar, Indonesia
}

\begin{abstract}
Abstrak
Tujuan Jumlah dan fungsi sel progenitor endotel menurun pada pasien dengan risiko penyakit kardiovaskular. Di sisi lain, pada hipertensi terdapat peningkatan angiotensin II yang dapat meningkatkan marker stress oksidatif sistemik yaitu F2-Isoprostan. Penelitian ini bertujuan mengetahui hubungan F2-Isoprostan dengan Stromal Cell-Derived Factor-1 (SDF-1) dan CD34 viable pada subjek nonhipertensi dan hipertensi.

Metode Penelitian dilakukan pada 54 subjek nonhipertensi dan 64 subjek hipertensi yang datang ke laboratorium klinik Prodia Jakarta. F2-Isoprostane (marker stres oksidatif) dan SDF-1 (faktor pertumbuhan sel stroma) diukur dengan metoda ELISA. CD34 viable (marker sel progenitor endotel) diukur dengan metoda flow cytometri.

Hasil Konsentrasi F2-Isoprostan lebih tinggi pada subjek hipertensi dibandingkan subjek nonhipertensi, namun secara statistic tidak signifikan ( $m \pm S D: 0,13 \pm 0,20$ vs 0,10 $\pm 0,16 ; \rho g / m L ; p=0,091$ ). Konsentrasi SDF-1 lebih tinggi secara signifikan pada subjek hipertensi dibandingkan dengan subjek nonhipertensi $(2821,63 \pm 281,94 \mathrm{vs}$ $2623,04 \pm 356,28 \rho \mathrm{g} / \mathrm{mL} ; P<0,05)$. Konsentrasi CD34 viable lebih rendah secara signifikan pada subjek hipertensi dibandingkan dengan subjek nonhipertensi $(1,9 \pm 0,9 / \mu L v s 2,7 \pm 1,7 ; P<0,05)$. F2-Isoprostan mempunyai korelasi negative dengan konsentrasi CD34 viable dalam sirkulasi $(r=0.022, p<0.05)$ namun tidak mempunyai korelasi dengan SDF-1 ( $p>0.05)$
\end{abstract}

Kesimpulan F2-Isoprostan dan SDF-1 lebih tinggi, sedangkan CD34 lebih rendah, pada subjek hipertensi dibanding nonhipertensi. Diduga F2-Isoprostan mengganggu tingkat CD34 viable, terbukti dari korelasi negative antara F2isoprostan dan CD34. (Med J Indones 2010; 19:109-12)

\begin{abstract}
Aim Circulating endothelial progenitor cells (EPCs) are reduced in number and function in patients at risk for cardiovascular diseases. On the other hand, hypertension is related with excess angiotensin II which would lead to oxidative stress. In this study, we investigated the correlation between F2-Isoprostane (as marker of oxidative stress) with Stromal Cell-Derived Factor-1 (SDF-1) and CD34 viable in non hypertension and hypertension subjects.

Methods This was a cross sectional study conducted on 54 nonhypertension and 64 hypertension subjects visiting Prodia laboratory, Jakarta. F2-Isoprostane (as marker of oxidative stress) and SDF-1 (a strmal cell growth factor) were measured by ELISA method, and CD34 viable (marker of progenitor cell) was measured by flow cytometry.

Results F2-Isoprostane concentration was higher in hypertensive subjects compared to nonhypertensive subjects, although statistically non signifiant (mean \pm SD: $0.13 \pm 0.120$ vs $0.10 \pm 0.16 ; \rho g / m L ; p=0.091$ ). SDF-1 concentration was significantly higher in hypertensive subjects compare to nonhypertensive subjects $(2821.63 \pm 281.94$ vs $2623.04 \pm 356.28 \mathrm{\rho g} / \mathrm{mL} ; \mathrm{P}<0.05)$. CD34 viable level was significantly lower in hypertensive subjects compare to nonhypertensive subjects $(1.9 \pm 0.9 / \mu \mathrm{L}$ vs $2.7 \pm 1.7 ; \mathrm{P}<0.05)$. F2-Isoprostane had negative correlation with $\mathrm{CD} 34$ viable in circulation $(\mathrm{r}=0.022, \mathrm{p}<0.05)$ but no correlation with SDF-1 $(\mathrm{p}>0.05)$.

Conclusions F2-Isoprostane was higher, but CD34 was lower, in hypertensive subjects compared to nonhypertensive. It seems that high F2-Isoprostane impaired the CD34 viable level as shown by negative correlation between F2Isoprostane and CD34. (Med J Indones 2010; 19:109-12)
\end{abstract}

Key words: endothelial progenitor cell, F2-Isoprostan, hypertension, SDF-1

Elevated blood pressure are associated with significant mechanical endothelial injury and dysfunction ${ }^{1}$. Recent studies reveal that injured endothelial monolayer is regenerated by circulating bone marrow-derived endothelial progenitor cells (EPCs), which accelerates re-endothelialization and limits atherosclerotic lesion formation ${ }^{2}$. EPCs are characterized by the expression

Correspondence email to: johns_pratama@yahoo.com of cell markers CD34, CD133 and vascular endothelial growth factor receptor-2 (VEGFR-2) and by their ability to form endothelial integrity and vascular homeostasis ${ }^{3}$.

$\mathrm{F}_{2}$-Isoprostan has been characterized as a reliable method to determine status of enhanced oxidative stress and increased oxidative stress has been reported to be 
associated with increased excretion of $\mathrm{F}_{2}$-Isoprostan. Another study showed that $\mathrm{F}_{2}$-Isoprostan is increased in hypertensive patients compared with healthy normotensive subjects. ${ }^{4}$

The release of EPCs from bone marrow to the circulation is regulated by growth factors, enzymes, ligands and surface receptors ${ }^{5}$. Stromal cell-derived factor-1 (SDF-1) is considered as one of the key regulators for releasing hematopoietic stem cell from bone marrow to circulation. SDF-1 has also shown to induce CD34+ cell proliferation, mobilization and angiogenesis in vivo ${ }^{6}$.

On the other hand, recent studies revealed that circulating EPCs are reduced in number and function in patients at risk for cardiovascular disease by decreasing their mobilization from bone marrow and by reducing the half-life of the progenitor cells ${ }^{1,7}$. In hypertensive rats, the number of circulating EPCs is reduced, while EPCs from hypertensive patients show accelerated senescence and reduced telomerase activity ${ }^{2}$.

Several studies reported that oxidative stress plays an important role in atherogenesis. Oxidative stress is defined as the situation characterized by increased generation of free radicals that results in increased oxidative damage of biological structures. In this present study, we investigate the relationship between oxidative stress, which is represented by F2-isoprostane, EPC mobilizing factor, represented by SDF-1 and the number of CD34 viable in non hypertension and hypertension patients.

\section{METHODS}

This was a cross sectional study conducted on 54 non hypertensive and 64 hypertensive subjects visiting Prodia laboratory, Jakarta. Patients that fulfill inclusion and exclusion criteria were given inform consent to participate in this study. This study started from February-September 2009. Hypertension was diagnosed according to JNC VII, if systolic and diastolic blood pressure was equal to or higher than 140 and $90 \mathrm{mmHg}$, respectively, on two or more visit at 1 week interval. Patients with blood pressure below that criteria were classified as non hypertensive. Excluded from the study the participants having overt diabetic disease or any laboratory evidence of inflammation at the moment of blood collection. Participant receiving antihypertensive drug treatment were also excluded.
The study protocol was approved by Hasanuddin University Ethics Committee and all participants gave their informed consent to participate in the study.

\section{Assay of Biochemical Profile}

Venous blood was collected from all subjects following 10-12 hours fasting and serum was separated from whole blood after centrifugation and immediately kept at $-20^{\circ} \mathrm{C}$ until measurement. Triglycerides, high-density lipoprotein (HDL) cholesterol, low-density lipoprotein (LDL) cholesterol and glucose were determined by an enzymatic-colorimetric method (Advia 1800; Siemens Healthcare Diagnostics Inc, Deerfield, Illinois, USA). F2-isoprostane and SDF-1 were determined by ELISA method (R\&D Systems, Minneapolis, USA). CD34 viable was determined by flow cytometry method (FACSCalibur, BD Biosciences, San Jose, California, USA).

\section{Statistical Analysis}

Statistical analysis was performed using SPSS version 13.00 (SPSS Inc, Chicago, Illinois, USA). Values were expressed as the mean $\pm \mathrm{SD}$. Mann Whitney was used to compare variables between nonhypertensive and hypertensive subjects. Spearman's coefficients of correlation between study variables were calculated.

\section{RESULTS}

The characteristics of 54 nonhypertensive and 64 hypertensive subjects were summarized in Table 1.

Table 1. Subject characteristics

\begin{tabular}{lcll}
\hline & $\begin{array}{c}\text { Nonhypertensives } \\
(\mathrm{N}=54)\end{array}$ & $\begin{array}{l}\text { Hypertensives } \\
(\mathrm{N}=64)\end{array}$ & $P$ \\
\hline Age (years) & $47 \pm 9$ & $52 \pm 8$ & $<0.01$ \\
Waist circumference $(\mathrm{cm})$ & $87 \pm 10$ & $91 \pm 9$ & $<0.05$ \\
Systolic BP $(\mathrm{mmHg})$ & $127 \pm 5$ & $143 \pm 11$ & $<0.01$ \\
Diastolic BP $(\mathrm{mmHg})$ & $81 \pm 4$ & $92 \pm 7$ & $<0.01$ \\
LDL cholesterol $(\mathrm{mmol} / \mathrm{l})$ & $138.9 \pm 30$ & $135.8 \pm 32$ & $>0.05$ \\
HDL cholesterol (mmol/l) & $47 \pm 9$ & $50 \pm 10$ & $>0.05$ \\
Triglycerides $(\mathrm{mmol} / \mathrm{l})$ & $132.6 \pm 58.8$ & $138.2 \pm 63.9$ & $>0.05$ \\
Fasting glucose $(\mathrm{mmol} / \mathrm{l})$ & $94.8 \pm 9.6$ & $95.8 \pm 11.6$ & $>0.05$ \\
\hline
\end{tabular}

BP, blood pressure; LDL, low-density lipoprotein; HDL, high-density lipoprotein. Values are mean $\pm \mathrm{SD}$.

$\mathrm{F}_{2}$-Isoprostane was higher in hypertensive subjects compare to nonhypertensive subjects but not statistically different (mean $\pm \mathrm{SD}, 0.13 \pm 0.20$ vs $0.0978 \pm 0.16$; pg/ $\mathrm{mL} ; \mathrm{p}=0.091$ ). (Figure. 1 ) 


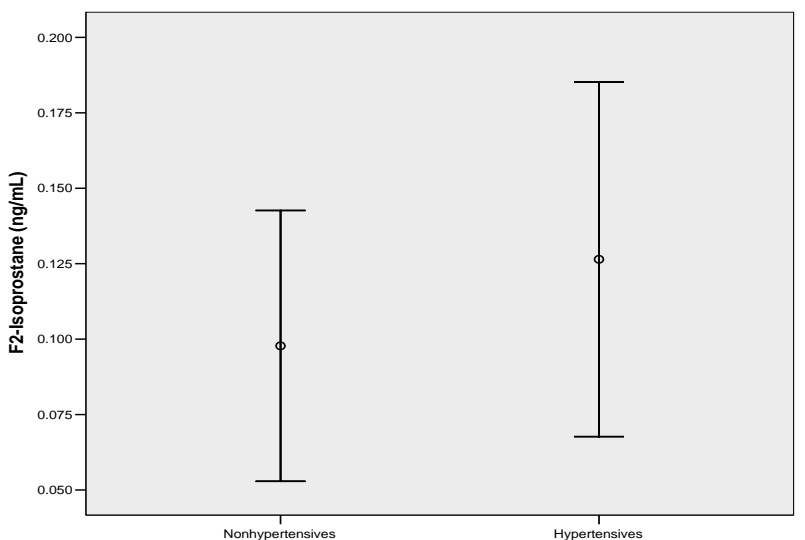

Figure 1. Difference concentration of F2-isoprostane in nonhypertensive and hypertensive subjects

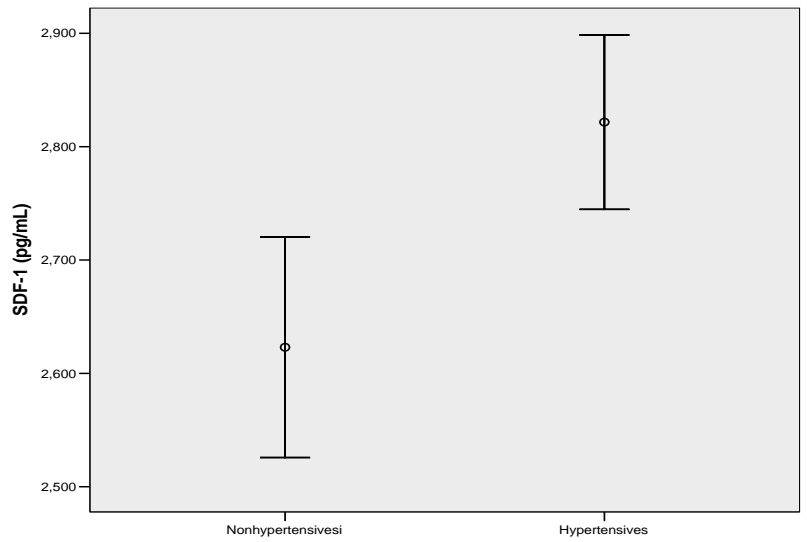

Figure 2. Difference concentration of SDF-1 in nonhypertensive and hypertensive subjects

SDF-1 was higher significantly in hypertensive patients compare to nonhypertensive patients (mean $\pm \mathrm{SD}$, $2821.63 \pm 281.94$ vs $2623.04 \pm 356.28 \mathrm{pg} / \mathrm{mL} ; \mathrm{P}<$ 0.05). (Fig. 2)

CD34 viable was lower significantly in hypertensive patients compare to nonhypertensive patients (mean \pm $\mathrm{SD}, 2.7 \pm 1.7$ vs $1.9 \pm 0.9 / \mu \mathrm{L} ; \mathrm{P}<0.05)$

$\mathrm{F}_{2}$-Isoprostane had negative correlation with $\mathrm{CD} 34$ viable in circulation $(\mathrm{p}<0.05)$.

In this study we found no correlation between $\mathrm{F}_{2}$ Isoprostane with SDF-1 $(p>0.05)$ and no correlation between SDF-1 with CD34 viable $(\mathrm{p}>0.05)$.

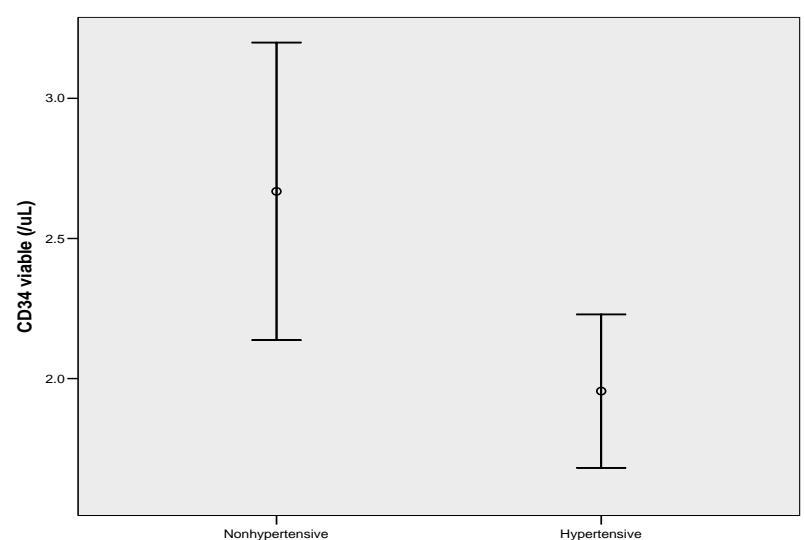

Figure 3. Difference concentration of CD34 viable in nonhypertensive and hypertensive subjects

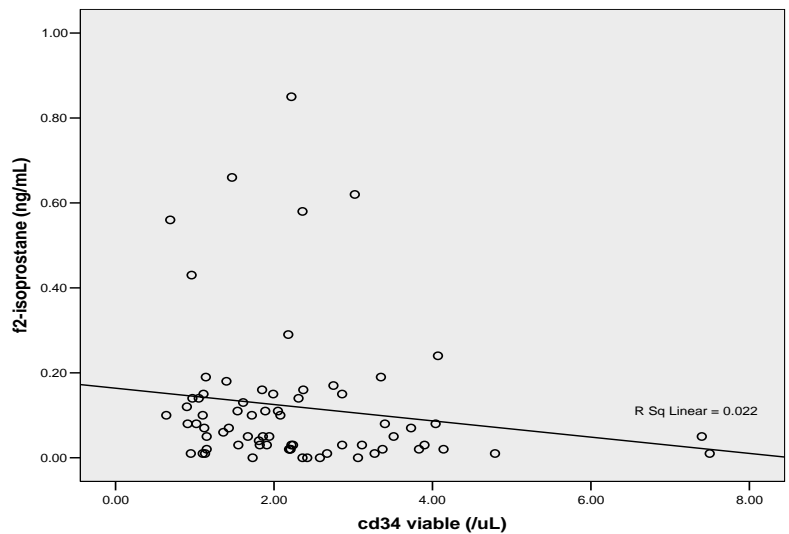

Figure 4. Correlation between F2-isoprostane concentration and CD34 viable level

\section{DISCUSSION}

The main finding of our study was that increased oxidative stress would lead to the impaired EPCs number and function in hypertensive subjects. This hypothesis was supported by our observation of a negative association between $\mathrm{F}_{2}$-isoprostane concentration and CD34 viable level and also that hypertensive subjects had higher concentration of $\mathrm{F}_{2}$-isoprostane and lower level of CD34 viable compared to nonhypertensive subjects.

In this study, we found that $\mathrm{F}_{2}$-Isoprostane was higher in hypertension compare to nonhypertension. Activation of vascular $\mathrm{NAD}(\mathrm{P}) \mathrm{H}$ oxidase, xanthine oxidase and 
endothelial nitric oxidase synthase have been implicated in increased superoxide generation in experimental hypertension. More studies, demonstrated that increased ROS production occured in patients with essential hypertension, renovascular hypertension and malignant hypertension. ${ }^{8,9}$ Accumulation of ROS by products from oxidized genomic and mitochondrial DNA has also been demonstrated in hypertensive individuals. ${ }^{10}$

Haendeler et al, showed an association between the accumulation of reactive oxygen species (ROS) and cellular senescence in matured endothelial cells. Imanishi et al, demonstrated that cultured EPCs exposed to angiotensin II (Ang II) would increased gp91phox expression in EPC, which contributed to superoxide production and accelerated the onset of EPC senescence. ${ }^{11}$ Ma et al, revealed that oxidized LDL decreased EPC survival and impaired their adhesive, migratory and tube-formation capacities in a dose-dependent manner. ${ }^{12}$

SDF-1 was a strong chemoattractant for CD34 cells, which express CXCR4 receptor for CD34, and played an important role in hematopoietic stem cell trafficking between peripheral circulation and bone marrow. SDF-1 may have direct effects on vasculogenesis. Plasma elevation of SDF-1 induced mobilization of mature and immature hematopoietic progenitors and stem cells including $\mathrm{EPCs}^{6}$. In this study, we found that in hypertensive subjects, SDF-1 concentration was increased but the levels of CD34 cells were decreased. The increasing level of SDF-1 would induce matrix metalloproteinases (MMPs) production. These MMPs cleave the cytokine SDF-1, which is released by stromal cells and its receptor CXCR4 on stem and progenitor cells. In this study, we found that SDF-1 was higher in hypertension compare to nonhypertension, which was supposed to be lower in hypertension. We assumed that in this case, the hypertensive subjects were newly diagnosed with high blood pressure that can be seen in their age which were in between 54 years, and besides, due to the increasing hemodynamic pressure, which was showed by the increased blood pressure, might induce MMP to release SDF-1 through the cleavage of CXCR4 reseptor. This was a compensatorye mechanism to maintain the physiological system in human body.

In this study we found that, hypertension which has been generally accepted to increase oxidative stress has a negative correlation with CD34 viable which will contribute to EPC dysfunction in the future and lead to the progression of end organ damage. What interesting in our study was, we found that in the early stage of hypertension, human body counteract the increaseing of oxidative stress oxidative by releasing SDF-1 to induce stem cell to mobilize to peripheral circulation. But uUnfortunately, SDF-1 could not help much to increase CD34 cells which was shown by the lower concentration of CD34 viable cells.

Inconclusion, $\mathrm{F}_{2}$-Isoprostan was higher, and CD34 was lower in hypertensive subjects compared to non hypertensive. It is assumed that the increasing concentration of $\mathrm{F}_{2}$-Isoprostane will contribute to EPC dysfunction as shown by impaired CD34 viable level.

\section{REFERENCES}

1. Pirro M, Schillaci G, Menecali C, et al. Reduced number of circulating endothelial progenitor cell and HOXA9 expression in $\mathrm{CD}_{3} 4^{+}$cells of hypertensive patients. J Hypertens 2007;25:2093-9.

2. Imanishi $\mathrm{T}$, Moriwaki $\mathrm{C}$, Hano $\mathrm{T}$, et al. Endothelial progenitor cell senescence is accelerated in both experimental hypertensive rats and patients with essential hypertension. J Hypertens 2005;23:1831-7.

3. Tousoulis D, Ionannis A, Antoniades C, et al. Role of inflammation and oxidative stress in endothelial progenitor cell function and mobilization : therapeutic implications for cardiovascular diseases. Atherosclerosis 2008;201:236-47.

4. Minuz P, Patrignani P, Gaino S et al. Increased oxidative stress and platelet activation in patients with renovascular disease. Circulation 2002;106:2800-5.

5. Hristov M, Erl W, Weber PC. Endothelial progenitor cell mobilization, differentiation, and homong. Arterioscler Thromb Vasc Biol 2003;23:1185-9.

6. Yamaguchi J, Kusano KF, Masuo O, et al. Sromal cellderived factor-1 effects on ex vivo expanded endothelial progenitor cell recruitment for ischemic neovascularization. Circulation 2003;107:1322-8.

7. Zonneveld AJ, Rabelink TJ. Endothelial progenitor cells: biology and therapeutic potential in hypertension. Curr Opin Nephrol Hypertens 2006; 15:167-72.

8. Imanishi T, HanoT, Nishio I. Angiotensin II accelerates endothelial progenitor cell senescence through induction of oxidative stress. J Hypertens 2005;23:97-104.

9. Higashi Y, Sasaki S, Nakagawa K, et al. Endothelial function and oxidative stress in renovascular hypertension. N Engl J Med 2002;346:1954-62.

10. Lip GY, Edmunds E, Nuttall SL, et al. Oxidative stress in malignant and non-malignant phase hypertension. J Hum Hypertens 2002;16:333-6.

11. Redon J, Oliva MR, Tormos C, et al. Antioxidant activities and oxidative stress byproducts in human hypertension. Hypertension 2003;41:1096-101.

12. Ma FX, Zhou B, Chen Z, et al. Oxidized low density lipoprotein impairs endothelial progeniotr cells by regulation of endothelial nitric oxide synthase. J Lipid Res 2006;47:1227-37.

13. Aicher A, Zeiher AM, Dimmeler S. Mobilizing endothelial progenitor cells. Hypertension 2005;45:321-5 
114 Wijaya et al. 